\title{
Lung Cancer cM1 TNM Finding v8
}

National Cancer Institute

\section{Source}

National Cancer Institute. Lung Cancer CM1 TNM Finding v8. NCI Thesaurus. Code C136434.

Lung cancer with distant metastasis. (from AJCC 8th Ed.) 